\title{
Mobbing Behaviors of the Players and its Effect on the Coaches: a Cogitation on Job Satisfaction
}

\section{Yasin Yildiz Aydin, Turkey \\ Study Area: Aydin, Turkey \\ Coordinates: $37^{\circ} 50^{\prime} 53^{3}$ N $27^{\circ} 50^{\prime} 43$ ? E}

Aydin Adnan Menderes University, Faculty of Sports Sciences,

Key words: :Trainer, Profession, Abusing, Pleasure

\section{Abstract}

We examined the effect of negative behaviours (mobbing) to which coaches are exposed in their work environments on their job satisfaction. "Minnesota Satisfaction Questionnaire" and "Negative Acts Questionnaire" were used as data collection tools. The data were collected from coaches working at Youth Services and Sports Directorates in the Aegean region. As a result of the reliability analysis of the scales, Cronbach's alpha value was found to be 0.834 for the Negative Acts Questionnaire and 0.082 for the Minnesota Satisfaction Questionnaire. Cronbach's alpha value was found to be 0.842 for the Internal Satisfaction subdimension of the job satisfaction scale, and 0.774 for the External Satisfaction subdimension. In order to determine the effect of mobbing behaviour on job satisfaction, simple regression analysis was performed, as a result of which mobbing was determined to have a negative effect on job satisfaction ( $(=-0.579)$. In addition, it was determined that mobbing had a negative effect on the internal satisfaction subdimension ( $(=-0.528)$ and the external satisfaction subdimension ( $(=-0.659)$. According to these results, it was revealed that mobbing negatively affected job satisfaction

the ethical and moral aspects of developing societies (Görmüs, 2020). In its general sense, job satisfaction expresses to what extent employees like their jobs (Spector, 1997). As can be understood from all these definitions, high or low level of job satisfaction affects employees and therefore the harmony level of the organization. In the absence of such harmony, job dissatisfaction can emerge. As a result of job dissatisfaction, adverse situations such as not being happy about his/her work, stress, anxiety, fatigue, etc. can develop in individuals (Çolak, 2017; Eginli, 2009). At the same time, it has been observed that the strength of the employees' commitment to the organization positively affects organizational performance and job satisfaction, and in this framework, organizational commitment reduces undesirable consequences such as a decrease in work performance and quitting, as well as positively contributing to product or service quality (Aydin, 2017).

A Swedish medical doctor, Paul Heinemann, used the term "mobbing" in order to define a series of actions such as bullying and violence he observed among children (Davenport et al., 2003). Mobbing means psychological harassment in which thevictim is exposed to systematic and

*Author: yasin.yildiz@adu.edu.tr 
permanent violence and suffers from oppression in the workplace (Tong, 2017). The basic feature of mobbing is that the victim has difficulty in coping with the situation and it leaves a permanent and negative effect on the individual (Einarsen, 2000). Mobbing can also be defined as one or a few employees in a workplace being systematically exposed to emotionally harming behaviors by one or a few employees every day or for a few months (Gökçe, 2008). It has been observed that individuals exposed to mobbing experience psychological depression, and their job efficiency and satisfaction are negatively affected. Victims of mobbing reported about suffering from anxiety, depression, sleep problems, nervousness, loss of concentration, and somatic symptom disorders (Nielsen, 2012).

In the study, it was aimed to investigate the effect of negative situations that coaches are exposed to in their working environments on their job satisfaction. The study is of importance in that it is expected to contribute to noticing the effect of mobbing behaviors on coaches, which makes the occupation of coaching a challenging job.

\section{Materials and Methods:}

The universe of the study, which was carried out in the general screening model (Karasar, 2005), consisted of coaches working at Youth and Sports Directorates. The questionnaires were administered to the participants through Google Forms, and participation in the study was voluntary. A total of 200 individuals were reached, and 31 of the 200 forms were not evaluated due to missing or erroneous information, so 169 forms were included in the analysis. The questionnaire of the study used to collect the data consisted of three sections. The first section contained demographic information, the second section was comprised of the "Negative Acts Questionnaire" which aimed to determine the status of coaches being exposed to mobbing, and the third section included the "Minnesota Satisfaction Questionnaire."

As a data collection tool for job satisfaction, the Minnesota Satisfaction Questionnaire (MSQ) short form, developed by Weiss, Davis, England, and Lofguist (1967) and the adaptation to Turkish and reliability and validity studies of which were performed by Baycan (1985), was used. The lowest score to be obtained from the questionnaire is 20, and the highest score is 100.12 items of the questionnaire measures job satisfaction regarding internal factors and 8 items are related to job satisfaction regarding external factors.

- (Internal Satisfaction): is measured by items 1, 2, 3, 4, 7, $8,9,10,11,15,16,20$.

- (External Satisfaction): is measured by items 5, 6, 12, 13, $14,17,18,19$.

In order to determine mobbing, "Negative Acts Questionnaire", developed by Einarsen \& Raknes (1997) and adapted to Turkish by Cemaloglu (2007), was used. The questionnaire is a 5-point Likert type scale that aims to determine the level of being exposed to negative behaviors by identifying the frequency of mobbing behavior through the options of "Never, Sometimes, Every Day, Every Week, Every Month." The data obtained were statistically analyzed by using the SPSS 25.0 package program. Statistically, frequency, percentages, and reliability coefficients were calculated. In addition, correlation analysis and simple regression analysis (to determine the effect of mobbing on job satisfaction) were performed. The reliability of the questionnaire was determined through Cronbach's alpha coefficient.

In the next step, extreme values in the data set and whether multivariate normality assumption was met were analyzed through Mahalanobis distance values, and the data that showed outlier property were excluded from the data set.

\section{Results:}

Table 1. Participants' Demographic Variables

\begin{tabular}{|c|c|c|c|c|c|c|}
\hline Parameter & Category & $\mathrm{F}$ & $\%$ & Category $\mathrm{F}$ & & $\%$ \\
\hline Gender & $\begin{array}{l}\text { Female } \\
\text { Total }\end{array}$ & $\begin{array}{l}40 \\
169\end{array}$ & $\begin{array}{l}23.7 \\
100\end{array}$ & Male & 129 & 76.3 \\
\hline Age & $\begin{array}{l}20-24 \\
30-34 \\
\text { Total }\end{array}$ & $\begin{array}{l}25 \\
44 \\
169\end{array}$ & $\begin{array}{l}14.8 \\
26 \\
100\end{array}$ & $\begin{array}{l}25-29 \\
35 \text { \& above }\end{array}$ & $\begin{array}{l}36 \\
64\end{array}$ & $\begin{array}{l}21.3 \\
37.9\end{array}$ \\
\hline $\begin{array}{l}\text { Marital } \\
\text { Status }\end{array}$ & $\begin{array}{l}\text { Single } \\
\text { Total }\end{array}$ & $\begin{array}{l}97 \\
169\end{array}$ & $\begin{array}{l}57 \cdot 4 \\
100\end{array}$ & Married & 72 & 43.6 \\
\hline Education & $\begin{array}{l}\text { High Sch. } \\
\text { Post-graduate }\end{array}$ & $\begin{array}{l}16 \\
35\end{array}$ & $\begin{array}{l}9.5 \\
20.7\end{array}$ & $\begin{array}{l}\text { University } \\
\text { Total }\end{array}$ & $\begin{array}{l}118 \\
169\end{array}$ & $\begin{array}{l}69.8 \\
100\end{array}$ \\
\hline $\begin{array}{l}\text { Cadre } \\
\text { Status }\end{array}$ & $\begin{array}{l}\text { Contracted } \\
\text { Total }\end{array}$ & $\begin{array}{l}93 \\
169\end{array}$ & $\begin{array}{l}55 \cdot 1 \\
100\end{array}$ & Tenure & 76 & $44 \cdot 9$ \\
\hline Working D & Duration in the & Org & nizatio & & & \\
\hline & $\begin{array}{l}0-3 \text { yrs } \\
8-11 \text { yrs } \\
16 \text { yrs \& above }\end{array}$ & $\begin{array}{l}69 \\
27 \\
16\end{array}$ & $\begin{array}{l}40.8 \\
16 \\
9.4\end{array}$ & $\begin{array}{l}4-7 \text { yrs } \\
12-15 \text { yrs } \\
\text { Total }\end{array}$ & $\begin{array}{l}52 \\
5 \\
169\end{array}$ & $\begin{array}{l}30.8 \\
3 \\
100\end{array}$ \\
\hline $\begin{array}{l}\text { Coaching } \\
\text { history }\end{array}$ & $\begin{array}{l}0-3 \text { yrs } \\
8 \text {-11 yrs } \\
16 \text { yrs \& above }\end{array}$ & $\begin{array}{l}32 \\
35 \\
19\end{array}$ & $\begin{array}{l}18.9 \\
20.7 \\
11.3\end{array}$ & $\begin{array}{l}\text { 4-7 yrs } \\
12-15 \text { yrs } \\
\text { Total }\end{array}$ & $\begin{array}{l}64 \\
19 \\
169\end{array}$ & $\begin{array}{l}37 \cdot 9 \\
11.2 \\
100\end{array}$ \\
\hline
\end{tabular}

Scale and Subdimensions Cronbach's Alpha Coefficient

1. Negative Acts Questionnaire.834

2. Minnesota Satisfaction Scale.882

2.1. Internal Satisfaction Subdimension. 842

2.2. External Satisfaction Subdimension.774

In the reliability analysis performed in order to determine the internal consistency of Negative Acts Questionnaire, Cronbach's alpha value was found to be o.83, while in the reliability analysis performed to determine the internal consistency of Minnesota Satisfaction Questionnaire, Cronbach's alpha value was determined as o.88. Besides, Cronbach's alpha values of the Internal Satisfaction sub-dimension and the External Satisfaction sub-dimension of Minnesota Satisfaction Questionnaire were found to be 0.84 and 0.77 , respectively. 
Table 4: The Effect of Participants' Mobbing Scores on Their Scores Obtained from Job Satisfaction

\begin{tabular}{|c|c|c|c|c|c|c|c|c|c|c|}
\hline $\begin{array}{l}\text { Dependent } \\
\text { Variable }\end{array}$ & $\begin{array}{l}\text { Independent } \\
\text { Variable }\end{array}$ & $?$ & St. Error & Beta & $\mathrm{T}$ & $\mathrm{P}$ & $\mathrm{F}$ & $\begin{array}{l}\text { Model } \\
\text { (p) }\end{array}$ & $\mathrm{R}_{2}$ & $\begin{array}{l}\text { Durbin } \\
\text { Watson }\end{array}$ \\
\hline Job & Constant & $4 \cdot 580$ & .205 & - & 22.339 & $0.000 *$ & $17 \cdot 939$ & $0.000 *$ & 0.099 & 2,077 \\
\hline Satisfaction & Mobbing & -.579 & .137 & -.323 & -4.235 & $0.000 *$ & & & & \\
\hline
\end{tabular}

Table 5: The Effect of Participants' Mobbing Scores on Their Scores Obtained from Internal Satisfaction Subdimension

\begin{tabular}{|c|c|c|c|c|c|c|c|c|c|c|}
\hline $\begin{array}{l}\text { Dependent } \\
\text { Variable }\end{array}$ & $\begin{array}{l}\text { Independent } \\
\text { Variable }\end{array}$ & $\bar{B}$ & St. Error & Beta & $\mathrm{T}$ & $P$ & $\bar{F}$ & $\begin{array}{l}\text { Model } \\
\text { (p) }\end{array}$ & $\mathrm{R}_{2}$ & $\begin{array}{l}\text { Durbin } \\
\text { Watson }\end{array}$ \\
\hline Internal & Constant & 4.709 & .210 & - & 22.427 & $0.000 *$ & 14.218 & $0.000 *$ & 0.079 & 2,017 \\
\hline Satisfaction & Mobbing & -.528 & .140 & -.291 & -3.771 & $0.000 *$ & & & & \\
\hline
\end{tabular}

Table 6: The Effect of Participants' Mobbing Scores on Their Scores Obtained from External Satisfaction Subdimension

\begin{tabular}{|c|c|c|c|c|c|c|c|c|c|c|}
\hline $\begin{array}{l}\text { Dependent } \\
\text { Variable }\end{array}$ & $\begin{array}{l}\text { Independent } \\
\text { Variable }\end{array}$ & B & St. Error & Beta & $\mathrm{T}$ & $\mathrm{P}$ & $\mathrm{F}$ & $\begin{array}{l}\text { Model } \\
\text { (p) }\end{array}$ & $\mathrm{R}_{2}$ & $\begin{array}{l}\text { Durbin } \\
\text { Watson }\end{array}$ \\
\hline External & Constant & 4.392 & .260 & & 16.880 & $0.000 *$ & 14.449 & $0.000^{*}$ & 0.080 & 1,980 \\
\hline Satisfaction & Mobbing & -.659 & .173 & -.293 & -3.801 & $0.000 *$ & & & & \\
\hline
\end{tabular}

Table 3: Analysis Results for Correlation Between Variables

\begin{tabular}{llllc}
\hline & 1 & 2 & 3 & 4 \\
\hline 1-Mobbing & 1 & & $\left(\mathrm{p}<0, \mathrm{O1}^{* *}, \mathrm{p}<\mathrm{O}, 05^{*}\right)$ \\
2-Job satisfaction & $-.323^{* *}$ & 1 & & \\
3-Internal satisfaction & $.291^{* *}$ & $.919^{* *}$ & 1 & \\
4-External satisfaction & $.293^{* *}$ & $.879^{* *}$ & $.621^{* *}$ & 1 \\
\hline
\end{tabular}

As per Table-3, mobbing has a significant and negative relationship with job satisfaction $(\mathrm{r}=-.323)$, internal satisfaction $(\mathrm{r}=.291)$ and external satisfaction $(\mathrm{r}=293)$ at 0.01 significance level. This result shows that oneunit increase in mobbing would decrease job satisfaction.

As per the regression analysis results, when the significance level that corresponds to $\mathrm{F}$ value is examined, it is seen that the model established is statistically significant $(\mathrm{F}=17.939 ; \mathrm{p}<0.05)$. When beta coefficient value, $\mathrm{t}$ value and a significance level of the independent variable are examined, it is seen that mobbing has a statistically significant effect on job satisfaction $(\mathrm{t}=-4.235 ; \mathrm{p}<0.05)$. It is seen that it explains $9.9 \%$ of the change observed in job satisfaction (Arranged $\mathrm{R}^{\wedge} \mathbf{2}=\mathbf{0 . 0 9 9}$ ). A one-unit increase in mobbing leads to a decrease in job satisfaction by $0.579(\Omega=-0.579)$.

As per the results of the regression analysis, when the significance level that corresponds to $F$ value is examined, it is seen that the model established is statistically significant $(\mathrm{F}=14.286 ; \mathrm{p}<0.05)$. When beta coefficient value, $t$ value and a significance level of the independent variable are examined, it is seen that mobbing has a statistically significant effect on internal satisfaction $(\mathrm{t}=-3.771 ; \mathrm{p}<0.05)$. It is seen that it explains $7.9 \%$ of the change observed in internal satisfaction (Arranged $\left.\mathrm{R}^{\wedge} 2=0.079\right)$. A one-unit increase in mobbing leads to a decrease in internal satisfaction by $0.528(\Omega=-0.528)$.

As per the results of the regression analysis, when the significance level that corresponds to $\mathrm{F}$ value is examined, it is seen that the model established is statistically significant $(\mathrm{F}=14.449 ; \mathrm{p}<0.05)$. When beta coefficient value, $t$ value and a significance level of the independent variable are examined, it is seen that mobbing has a statistically significant effect on external satisfaction $(\mathrm{t}=-3.801 ; \mathrm{p}<0.05)$. It is seen that it explains $8.0 \%$ of the change observed in external satisfaction (Arranged $\mathrm{R}^{\wedge} 2=0.080$ ). A one-unit increase in mobbing leads to a decrease in external satisfaction by-0.659 ( $(=-0.659)$.

\section{Discussion:}

The human factor is primarily important in the success of organizations. It is the human factor that ensures the establishment and functioning of organizations and gets them to move towards certain objectives. Therefore, the efficiency of the organization will increase in parallel to the qualities of the individual. In this context, it should be emphasized that psychological mobbing is a phenomenon that emerges specifically in the workplace (Çavuș \& Demir, 2009).

Mobbing behavior is considered a serious threat aimed at a human being, who is the most valuable source of society and organizations. Mobbing, which can be seen in almost all occupational groups in working life, is less in the foreground compared to physical violence as employees do not prefer to mention this situation to anyone. Due to its negative effects on employees and therefore on organizations, many studies are being carried out on this topic. Accordingly, in the present study, mobbing issues were discussed, and the effect of mobbing behavior on job satisfaction was examined (Gül \& Özcan, 2011).

When Table- 3 is analysed, it is seen that there is a significant and negative relationship between mobbing and job satisfaction. This result shows that a one-unit increase in mobbing would decrease job satisfaction. In a parallel study to the present study conducted by Arici (2019), the effect of mobbing behaviors on job satisfaction was analyzed through Fisher's $\mathrm{Z}$ analysis, and the mean impact size was found to be -0.368 ( $S D=0.189$ ). Accordingly, it was determined that mobbing had a moderate and negative effect on nurses' job satisfaction. In line with this negative result obtained, nurses being exposed to mobbing decreased their job satisfaction; in other words, their job satisfaction was moderately affected and decreased. It was concluded that as the amount of mobbing increased, nurses'job satisfaction decreased.

When Table- 4 is analysed, it is seen that mobbing has a statistically significant effect on the duration of job satisfaction. It is also seen that mobbing explains $9.9 \%$ of the change in job satisfaction. A one-unit increase in mobbing leads to a decrease of -0.579 in job satisfaction. 
Dur (2019), Karakullukçu (2015), and Sever (2017), determined that the participants' average scores related to internal satisfaction, external satisfaction, and overall satisfaction did not significantly differ according to the variable of the number of working years, which supports our study results. In similar research close to the subject, Özmaden (2019) related to leisure and life satisfaction were investigated, it was determined that there was a positive relationship between all sub-scales of leisure satisfaction and life satisfaction.

In Table-5, it is seen that mobbing has a statistically significant effect on internal satisfaction. It is also seen that it explains $7.9 \%$ of the change in job satisfaction (Arranged $=0.079)$. A one-unit increase in mobbing causes a decrease of -0.528 in job satisfaction $(\beta=-0.528)$. Talas (2016) determined that regarding internal satisfaction, nurses were not satisfied with their occupation in terms of working conditions, the opportunity of working independently, the opportunity to be recognized as a respectable person in society, and the opportunity to use their own ideas/opinions freely. In relation to the job they did, nurses reported that they did not experience the satisfaction of dissatisfaction in terms of the feeling of achievement they felt, they are being given the chance to have conscientious responsibility, or they are being provided a guaranteed future.

When Table-6 is analysed, it is seen that mobbing has a statistically significant effect on external satisfaction. It is also seen that it explains $8.0 \%$ of the change in job satisfaction. A one-unit increase in mobbing leads to a decrease of -0.659 in job satisfaction $(\beta=-0.659)$. Talas (2016) determined that in relation to the external satisfaction subdimension of job satisfaction, nurses were not happy with the salary they were paid in exchange for the work they did and that they were dissatisfied in terms of not being given the opportunity to be promoted, the managers' approach to them, the inadequacy of the managers in making decisions, and not being given the chance to use their own methods in the work they did.

\section{Suggestion:}

Suggestions related to protection against and elimination of these situations that are considered to be caused by mobbing can be listed as follows:

- In the management of the organization, coaches, trainers and all staff should be provided with transparency, and an equal and fair management approach should be adopted.

- Since approaching with common sense would prevent possible problems from developing and maintain the motivation of coaches, managers should adopt such behaviors.

- Managers, coaches and trainers in the organization should communicate with each other by understanding an issue and without provoking the other party, and should empathize when necessary.

- Managers should deal with events and situations through reasoning by noticing them, and should not exert personal pressure on individuals.

- They should firstly listen to the issues, then evaluate them within the framework of laws and regulations, and make decisions accordingly and take actions independently of emotions.

- Issues should be evaluated as holistically rather than separately, and decisions should be made accordingly; complaints and performance evaluation mechanisms should be run in a healthyway.

- In recruitment processes, in addition to their competencies, individuals should be evaluated according to their personality characteristics and emotional intelligence, and it should be ensured that they do not have personality characteristics that may create problems in the working environment (Miller, 200o).

In order for coaches and trainers to have job satisfaction at the maximum level, rather than individualization, institutionalization in which everyone can work the most efficiently should be emphasized. Believing that the study conducted within this context will contribute to the literature, it is recommended that other studies should be carried out in terms of increasing job satisfaction of coaches and trainers.

\section{References:}

Arici, N. (2019): The Effect of Mobbing on Job Satisfaction of Nurses: A Meta-Analysis Study. Master's Thesis. Gazi University Health Sciences Institute, Ankara.

Aydin, A.S., Akyüz, K.C., Yildirim, I. \& Köse, S. (2017): Analysis of Teachers' Job Satisfaction and Organizational Commitment Levels. Int. Eco. Admin. Stud.J., 18:23-52.

Baycan, A. (1985): "Analysis of Several Aspects of Job Satisfaction Between Different Occupational Groups". Bogaziçi University Social Sciences Institute, Master's Thesis, Istanbul.

Carriere J. \& Bourque C. (2009): The rffects of organizational communication on job satisfaction and organizational commitment in a land ambulance service and the mediating role of communication satisfaction. Career Dev. Int. 14:29-49.

Cemaloglu, N. \& Ertürk, A. (2007): Examination of mobbing behaviors to which teacher are exposed to in terms of gender. Tur. Edu. Sci.J., 5(2):345-362.

Çavus, M.F. \& Demir, Y. (2009): A Research on Individual and Organizational Effects of Mobbing. Nigde Uni. Economics Administrative Sci. Faculty J., 2(1):13-23.

Çolak, I., Altinkurt, Y. \& Yilmaz, K. (2017): The relationship between teachers' independent behaviors and job satisfaction. KSBD, Fall, 9(2):189-2o8.

Davenport, N., Schwartz, R.D. \& Eliot, G.P. (2003): Mobbing: Emotional Harassment in the Workplace. Pub. by : Translator: Önertoy OC. Istanbul.

Dur, S. (2019): The relationship of classroom teachers' worklife balance with organizational commitment and job satisfaction. Master's Thesis. Yildiz Technical University and Istanbul Aydin University Social Sciences Institute, Istanbul.

Eginli-Temel, A. (2009): Job satisfaction in employees: a research 


\section{ORIGINAL ARTICLE}

on job satisfaction of public and private sector employees. Atatürk Uni. Eco. AdministrativeSci.J., 23(3):37.

Einarsen, S. \& Raknes, B.L. (1997) Harassment in the Workplace and the Victimization of Men. Violence Victims, 12(4):247263.

Einarsen, S. (2000): Harassment and bullying at work: A review of the Scandinavian approach. Aggress Violent Behav., 5:379-401.

Gökçe, A.T. (2006): Mobbing in the Workplace: A research on Private and Primary School Teachers and Administrators. Doctoral Dissertation. Ankara University Educational Sciences Institute, Ankara. Turkey.

Görmüs, M. (2020): The effect of self-leadership behaviors on job satisfaction level in youth leaders. Master's Thesis. Karamanoglu Mehmetbey University Social Sciences Institute.

Karaman.Gül, H. \& Özcan, N. (2011): The relationships between mobbing and organizational silence: An empirical study in Karaman Provincial Administration. Kahramanmaras Sütçü Imam Uni. Eco. Administrative Sci.J.21(2):107-134.

Karakullukcu, I. (2015): Examination of the relationship between employees' organizational commitment and job satisfaction in organization using outsourcing method: Bolu Izzet Baysal Research and Training Hospital. Master's Thesis. Turkish Aviation Institute University Social Sciences Institute, Ankara.

Lu, H., Barriball, K.L., Zhang, X. \& While, A.E. (2012): Job satisfaction among hospital nurses revisited: a systematic review. Int JNurs Stud., 49:1017-1038.
Ambient Science, 2020: Vol. 07(Sp1); 125-129 DOI:10.21276/ambi.2020.07.sp1.oa02

Miller, K. (2000): They Call It "Mobbing”; A new kind of workplace harassment or an old one with a new name?, Either Way, Europe are upset. Newsweek, New York.

Nielsen, M.B., Hetland, J., Matthiesen, S.B. \& Einarsen, S. (2012): Longitudinal relationships between workplace bullying and psychological distress. Scand J Work Environ Health, 2012:38-46.

Özmaden, M. (2019): The Investigation of the Relationship between University Students' Leisure and Life Satisfaction Levels. Int. J. Progressive Edu., 15(2):91-103.

Sever, E. (2017): The mediating role of job satisfaction in the relationship between employee empowerment and organizational commitment: a research in industrial sector. Master's Thesis. Maltepe University Social Sciences Institute, Istanbul.

Spector, P. E. (1997): Job satisfaction: Application, assessment, cause, and consequences. Pub. by: Sage, California.

Talas, S. (2016): Analysis of the relationship between mobbing nurses are exposed to and job satisfaction. Master's Thesis. Istanbul Gelisim University Social Sciences Institute, Business Department, Istanbul.

Tong, M., Schwendimann, R. \& Zúñiga, F. (2017): Mobbing among care workers in nursing homes: A cross-sectional secondary analysis of the Swiss Nursing Homes Human Resources Project. Int. J. nursing studies, 66:72-81.

Weiss, D.J., Dawis, R.V., England, G.W. \& Lofquist, L.H. (1967): Manual for the Minnesota Satisfaction Questionnaire. Pub. by: Minneapolis, MN: University of Minnesota. 